\section{A manual for all seasons}

\author{
D. P. Lane
}

Gene Transfer and Expression: A Laboratory Manual. By M. Krieger. Macmillan/Stockton Press: 1990. Pp.242. £27.95, \$39.

Protein Methods. By D. M. Bollag and S. J. Edelstein. Wiley-Liss: 1991. Pp.230. $£ 24.50, \$ 29.95$.

Molecular Biology: Lab Fax. Edited by T. A. Brown. Blackwell/Academic: 1991. Pp.322. £21.95, \$49.95.

I AM a great fan of manuals, not just because I have written one myself. At their best, they give real power and inspiration to scientists. One of the most tedious phenomena in science is the 'expert'. This manifests itself in attempts to exclude other scientists from a given area because they are not expert immunologists, molecular biologists, embryologists and so on. We were all beginners once, and a good manual is truly subversive because it breaks down these prejudices and allows scientists to enter new areas with confidence. Manuals are also very cost-effective because they are much less expensive than most 'kits' for molecular or cellular biology. If they prevent a single failed experiment, then they have already paid for themselves. My unit of science is now the postdoc-minute, which is approximately 15 pence in UK currency, so of course one must take account of how long it takes to read the manual as well.

Gene Transfer and Expression is excellent. It is written in a wonderfully direct and clear style. It is very cost-effective, as postdoctoral researchers might even read it on holiday. It deals with an expert area that has not been covered in detail before. That is how to get your wretched gene expressed in eukaryotic cells. This is often the ratelimiting step if one wants to sell the gene to a biotechnology company and/or get it to show sufficient biological activity that one can obtain a publishable, perhaps even meaningful, result.

I particularly enjoyed the introductory chapters on the control of eukaryotic gene expression. They contain just the right amount of detail to allow the reader to make choices of host and vector. The protocols themselves, the heart of any manual, are also clear and direct. Their personal touch gives one hope that the author really knows they will work. What also shines through is the author's honesty. When he does not understand something, he says so rather than let it hang in the air. He is also happy to be specific about which machine and which chemical to buy. This is very helpful when starting out on a new technique. The book is very comprehensive and covers the whole area of eukaryotic expression from retroviral vec- tors to expression cloning.

Protein Methods is less satisfying. It deals with two major topics; preparation of protein extracts and gel electrophoresis of protein samples. In a way, this is not a bad mix of topics and the manual contains a lot of sensible points about the preparation of cell extracts. But the protocols are often sketchy or incomplete, and frequently refer the user to other manuals for a given step, which is very irritating. The section on gel electrophoresis, although reasonably comprehensive, does not really add anything to the many other texts that cover this area.

Molecular Biology: Lab Fax is not a manual, more a gigantic mutant appendix. It is full of the sort of information one finds in

\section{Meat and veg}

\section{May Berenbaum}

Plant-Animal Interactions: Evolutionary Ecology in Tropical and Temperate Regions. Edited by P. W. Price, T. M. Lewinsohn, G. W. Fernandes and W. W. Benson. Wiley: 1991. Pp.639. $\$ 125, £ 97.35$.

LoNG before it was politically fashionable biologists have had an appreciation for the tropics, not only for the breathtaking diversity of the flora and fauna, but also for the unique insights afforded by that diversity into the evolutionary processes influencing life on Earth. Over 100 years ago, A. R. Wallace wrote

To the student of nature ... the tropics will ever be of surpassing interest whether for the variety of forms and structures which it presents, for the boundless energy with which the life of plants is therein manifested, or for the help which it gives us in our search after the laws which have determined the production of such infinitely varied organisms.

Wallace would no doubt have approved of this latest volume. Publishing symposium proceedings on herbivory of various descriptions has become common practice of late, but Plant-A nimal Interactions distinguishes itself from the crowd by both its emphasis and its scope. The outcome of an international symposium conducted in Campinas, Brazil, in 1988, this book is refreshingly distinctive in its emphasis on tropical plantanimal interactions.

Although the editors indicate in the preface that the volume is not intended to be a "compendium of research on plant-animal interactions", they have nonetheless managed to pack an extraordinary amount of diversity between its covers. The majority of contributions focus on antagonistic interactions, but mutualistic interactions merit a section of their own. It is not surprising that plant-butterfly interactions are the focus of five chapters - tropical butterflies have attracted the attention of evolutionary ecologists ever since Henry Bates first speculated the better catalogues from molecular biology, radiochemical and chemical companies. Genotypes of bacteria, restriction sites, enzyme buffers, decay curves for ${ }^{125}$ I are all here. The book scores in my view because it has collected all these things together in one place, and although it will probably only inspire train-spotters, I think it is well worth getting.

Soon, I suppose, we will have manuals for every method and probably be updated continually by computer mail. Perhaps it is time to write a manual about thinking.

D. P. Lane, Cancer Research Campaign Laboratories, Medical Sciences Institute, Dundee University, Dundee DD1 4HN, UK.

about mimicry almost 130 years ago. But a rich diversity of nonlepidopteran herbivores are represented; there are chapters on twolegged (T. H. Fleming on frugivorous birds), four-legged (S. J. McNaughton on mammals), six-legged (nonlepidopterous insects of all descriptions) and even eight-legged (A. J. Heyneman et al. on hummingbird flower mites) herbivores. Although the majority of chapters describe basic research, at least three (M. Kogan, M. A. Altieri and M. A. Garcia) focus on agroecology. Even chapter structure varies; some chapters are strictly literature surveys, other are detailed experimental studies, and still others are summaries of many decades of research. Overall, the taxonomic, ecological and stylistic diversity provide for an endlessly entertaining and intellectually challenging read. The editors provide an excellent historical introduction to the book as a whole, as well as cogent and informative introductions to each of the six sections, so the book is thematically and stylistically cohesive.

If this collection has a weakness, it is the inclusion of chapters that focus exclusively or extensively on temperate herbivory. Individually, these contributions are of uniformly high quality; however, they seem out of place in this volume, the main emphasis of which is on tropical herbivores.

\section{IMAGE UNAVAILABLE FOR COPYRIGHT REASONS}

